\title{
Impact and Public Perception towards Agropolitan Area Development in Selupu, Rejang Rejang Lebong District, Bengkulu, Indonesia
}

\author{
Mya Novita Sari ${ }^{a^{*}}$, Rahmi Purnomowati ${ }^{\text {b }}$ \\ ${ }^{a}$ Stiper Rejang Lebong, Bengkulu, Indonesia \\ ${ }^{\mathrm{b}}$ Faculty of Science and Technology, Syarif Hidayatullah State Islamic University
}

\begin{abstract}
Development activities agropolitan in District Selupu Rejang continue to run until today, the development of infrastructure to support the agropolitan as a regional producer of vegetable production in the county, Rejang Lebong such as agribusiness terminal, opening up new avenues as access to transport production, irrigation infrastructure to facilitate mobility of factors, goods or services and inter-regional trade. The aims of this study are to analyze economic development through the poverty level shift with agropolitan development and to assess public perception of the impact of development activities agropolitan in District Selupu, Rejang Lebong regency, Bengkulu, Indonesia. The results of the analysis indicated that the development of agropolitan vegetables has had a positive impact on the welfare changes.
\end{abstract}

Keywords: Agropolitan, Welfare, Public perception

\section{Introduction}

The development of agribusiness systems and food security is both a goal and a goal of agricultural development. In order for agribusiness development to provide maximum benefit and impact for economic development and income increase of local community, a new approach in agribusiness development is needed. One of the approaches is creating an agropolitan model which essentially synergizes the development of agribusiness in the context of regional economic development, so that the total added value of agribusiness development can be benefited by the local community [1] [2].

Currently the government is increasingly paying attention to regional economic development through the jargon of political economy, such as economic decentralization, regional autonomy, and empowerment of small, medium and cooperative enterprises. But until now, there are not clear format and implementation Even further examined, the superficiality of applied macroeconomic policies is inconsistent and contradicts to the regional economic development efforts. Therefore, the implementation of agropolitan and agribusiness development in local economic development based on the agricultural sector is considered necessary. Rejang Lebong is a regency in Bengkulu Province, Indonesia, where the majority of economic activities is mostly agriculture, from 15 sub-districts in the regency of Rejang Lebong, 11 of which has the potential to be developed as an agropolitan area. The objectives of this research are 1) to analyze the shift of the poverty level in agropolitan area in the current year, 2) to analyze public perception about the impact of agropolitan development on agribusiness system, infrastructure, and socio-cultural condition.

\section{Research Method}

This research was conducted in Selupu, Rejang Rejang Lebong district, Bengkulu, Indonesia. Determining the location of the study was done through purposive sampling method because the area was a place of development of an agropolitan area development center in accordance with the criteria of the area to be studied. This research was conducted in 2014-2015 by employing secondary and primary data.

\subsection{Economic Improvement of Population Poverty Rate}

To determine the level of poverty was carried out by calculating the percentage of the number of prosperous households by using a formulation as follows:

$$
\operatorname{TKRTpSS1_{i,t}}=\left(\left(R T p S i, t+R T S 1_{i, t}\right) / R T_{i, t}\right) \times 100 \%[3]
$$

Where:

\begin{tabular}{|c|c|}
\hline TKRTpSS $1_{i, t}$ & $\begin{array}{l}\text { : Household Poverty Rate of } \\
\text { Pre Prosperous and } \\
\text { Prosperous I of Region i in } \\
\text { the Current Year } \mathrm{t}(\%)\end{array}$ \\
\hline $\mathrm{RTpS}_{\mathrm{i}, \mathrm{t}}$ & $\begin{array}{l}\text { Number of Pre-Prosperous } \\
\text { Households in the Current } \\
\text { Year } \mathrm{t}\end{array}$ \\
\hline $\operatorname{RTS} 1_{i, t}$ & $\begin{array}{l}\text { : Number of Prosperous } \\
\text { Household I of Region i in } \\
\text { the Current Year } t\end{array}$ \\
\hline $\mathrm{RT}_{\mathrm{i}, \mathrm{t}}$ & $\begin{array}{l}\text { : Number of Local } \\
\text { Households of Region i in } \\
\text { the Current Year } t\end{array}$ \\
\hline
\end{tabular}

2.2 Perception Analysis of Farmers on the Impact of Agropolitan Development Activities on Income

Measurement of farmer perceptions about the impact of agropolitan development activities was conducted by using a structured questionnaire on farmers' respondents. High level of perception is when many respondents feel the benefits of the agropolitan program. Questions in the questionnaire were assessed and the results of the total 
score for each respondent were grouped according to expectations.

\section{Results And Discussion}

\subsection{Changes in Poverty Level}

By using the percentage of the number of preprosperous and prosperous househhold I from the Village Potential Data issued by Central Bureau of Statistics, we obtain the result of the poverty rate change as indicated in table 1 .

Table 1. Changes in the poverty level

\begin{tabular}{|c|c|c|c|c|c|c|c|}
\hline \multirow{2}{*}{ No } & \multirow{2}{*}{ Districts } & \multicolumn{2}{|c|}{ PKMS II } & \multicolumn{2}{|c|}{ PKS I } & \multicolumn{2}{|c|}{ PKPS } \\
\hline & & 2008 & 2010 & 2008 & 2010 & 2008 & 2010 \\
\hline 1 & Curup & 21,7 & 16,4 & $-12,3$ & $-31,0$ & $-4,2$ & 117 \\
\hline 2 & $\begin{array}{l}\text { Curup } \\
\text { Timur }\end{array}$ & -1.2 & $-68,8$ & 6,8 & $-90,1$ & 2,9 & -84 \\
\hline 3 & $\begin{array}{l}\text { Curup } \\
\text { Utara } \\
\end{array}$ & 6,7 & $-17,2$ & $-14,5$ & 63,6 & $-12,4$ & -25 \\
\hline 4 & $\begin{array}{l}\text { Curup } \\
\text { Tengah }\end{array}$ & 16,9 & $-15,8$ & 23,5 & $-5,9$ & 23,0 & -24 \\
\hline 5 & $\begin{array}{l}\text { Curup } \\
\text { Selatan }\end{array}$ & 35,3 & 28,0 & $-48,3$ & 121,5 & $-61,3$ & 182 \\
\hline 6 & $\begin{array}{l}\text { Bermani } \\
\text { Ulu }\end{array}$ & $-53,1$ & 319,2 & 15,6 & 10,2 & $-26,0$ & 10 \\
\hline 7 & $\begin{array}{l}\text { Bermani } \\
\text { Ulu Raya }\end{array}$ & 1,8 & $-15,6$ & $-22,3$ & 86,0 & $-2,7$ & $\begin{array}{l}-17 \\
\end{array}$ \\
\hline 8 & $\begin{array}{l}\text { Selupu } \\
\text { Rejang }\end{array}$ & 24.8 & 10.7 & -19.7 & 13.9 & -30.2 & 12 \\
\hline 9 & $\begin{array}{l}\text { Sindang } \\
\text { Dataran }\end{array}$ & 29,7 & 14,2 & $-2,2$ & $-74,5$ & 89,5 & -91 \\
\hline 10 & $\begin{array}{l}\text { Sindang } \\
\text { Kelingi }\end{array}$ & 20,2 & 28,6 & 19,1 & $-31,3$ & $-38,0$ & -41 \\
\hline 11 & $\begin{array}{l}\text { Padang } \\
\text { Ulak } \\
\text { Tanding }\end{array}$ & 14,3 & $-9,3$ & 17,0 & 11,1 & $-21,8$ & 128 \\
\hline 12 & $\begin{array}{l}\text { Sindang } \\
\text { Beliti Ulu }\end{array}$ & 46,1 & 25,1 & 28,5 & 39,1 & $-60,6$ & 184 \\
\hline 13 & $\begin{array}{l}\text { Sindang } \\
\text { Beliti Ilir }\end{array}$ & 19,5 & $-42,8$ & 42,3 & $-83,7$ & $-13,6$ & $\begin{array}{l}-83 \\
\end{array}$ \\
\hline 14 & Binduriang & 8,0 & $-74,2$ & 21,2 & 4,1 & $-0,5$ & -46 \\
\hline 15 & $\begin{array}{l}\text { Kota } \\
\text { Padang } \\
\end{array}$ & 54,6 & $-87,5$ & $-16,5$ & $-40,9$ & $-10,7$ & 974 \\
\hline $\begin{array}{l}\text { Wher } \\
\text { PMK }\end{array}$ & & $\begin{array}{l}: \operatorname{Im}_{1} \\
\text { II }\end{array}$ & nent & omi & Pros & bus $\mathrm{H}$ & ehold \\
\hline $\begin{array}{l}\text { PKS I } \\
\text { PKPS }\end{array}$ & & $\begin{array}{l}\text { :Char } \\
\text { : Char }\end{array}$ & $\begin{array}{l}\text { of Pros } \\
\text { of Pre- }\end{array}$ & $\begin{array}{l}\text { erous } \mathrm{H} \\
\text { rospero }\end{array}$ & $\begin{array}{l}\text { useholc } \\
\text { House }\end{array}$ & & \\
\hline
\end{tabular}

Table 1 indicates that in each sub-district in Rejang Lebong Regency in 2008 and 2010 there is a change of poverty level where there is an increase in the prosperous household II, prosperous household I and pre-prosperous household. This is affected by the existence of supporting facilities and infrastructures such as facility transportation, financial institutions, marketing institutions and the application of agricultural technology. The greatest decrease level of prosperity in prosperous household II occurs in Bermani Ulu Sub-district as much as $319.2 \%$ of the head of household in 2010. This is caused by the annual coffee farming and both social facilities and infrastructures in the area have not been able to support the needs of the community. In the prosperous household I, the highest level of welfare decreases by $121,5 \%$, which occurs in South Curup sub-district where the people work for food crops, horticulture and outside agriculture sector. The decline in the welfare rate of pre-junior families is due to the low selling price of agricultural commodities and high farming costs but is not supported by good agricultural production due to the declining interest of the community to manage the agricultural sector. Moreover, in the pre prosperous household, the level of welfare in the urban sub-district is $974 \%$ in 2010 in which the area is a sub-district far from the city administration center and the area is a rubber plantation area with a low production productivity.

\subsection{Public's Perceptions of the Impact of Agropolitan Development}

\subsubsection{Public Perception Against Agribusiness System}

The impact of the agribusiness subsystem on the research indicates that there is a good impact of agropolitan development as indicated in table 2 .

Table 2. Public Perception Against Agribusiness System
\begin{tabular}{|l|l|l|l|}
\hline No & Items & Average scores & Categories \\
\hline 1 & Upstream Agribusiness & 3.321 & Moderate \\
\hline 2 & On-Farm & 3.301 & Moderate \\
\hline 3 & Processing & 2.953 & Moderate \\
\hline 4 & Marketing & 3.076 & Moderate \\
\hline 5 & Support & 2.917 & Moderate \\
\hline
\end{tabular}

Source: Processed primary data (2015)

The results in table 2 above indicate that the community has benefited from the agribusiness subsystem. Public perceptions of upstream agribusiness are good enough with the availability of seeds, farm equipment, fertilizers and pesticides and weeds from suppliers or input institutions. As for the community's response to the cultivation is moderate, it is because the community no longer just utilized traditional cultivation techniques due to the increasing knowledge of the community in the application of agricultural cultivation technology. Furthermore, the processing of agricultural products in this area is also moderate. The farmers sell their agricultural production without being processed due to lack of ability to perform processing activities and lack of innovating knowledge. Therefore, when there is a development of agropolitan area, there will many home industries manage the agricultural products from raw goods into ready-made goods. Public perception of agricultural marketing is moderate. This is caused by the distribution of agricultural products is good enough where farmers sell their products directly to traders who gather around their homes and farmers also no longer have to spend on transportation and labor costs where the collector directly transporting from the farmer's own land so that the farmer will not bear the post-harvest capital from the production of the farming.

Furthermore, in terms of sub-agribusiness supporting factors, based on community perceptions of these factors are also categorized as moderate. This is caused by a lot of information obtained by the community in the utilization of these factors and support of technical personnel or experts in improving the development and protection of market prices in this agropolitan area. Although farmers have to sell their products to the traders with low prices, but still it is above the price at the farmers level. 
Moreover, the perception of the institutional impact is indicated in table 3.

Table 3. Public Perceptions of Institutions

\begin{tabular}{|l|l|l|l|}
\hline No & Items & Average scores & Categories \\
\hline 1 & Cooperation & 2.937 & Moderate \\
\hline 2 & Government & 3.232 & Moderate \\
\hline 3 & Others & 3.112 & Moderate \\
\hline
\end{tabular}

Source: Processed primary data (2015)

Perceptions of the community of Selupu Rejang Subdistrict to the impact of financial institutions (cooperatives, banks) are moderate. This is due to the fact that the financial institutions available in the area have been well utilized by the community who live in the agropolitan area. This is affected by the information received by the community in conducting transactions and lending processes to financial institutions. Even though the place of financial institutions available in the Selupu Rejang Sub District is quite far from the community's residence, the existing financial institutions in this agropolitan area can still be used well by the community as a source of capital loans.

\subsubsection{Public Perceptions of Infrastructure Development}

The public perception in term of the perceived impacts on infrastructure development is indicated in table 4.

Table 4. Public Perceptions of Infrastructure

\begin{tabular}{|l|l|l|l|}
\hline No & Items & Average scores & Categories \\
\hline 1 & Location & 3.587 & Moderate \\
\hline 2 & Transportation & 3.158 & Moderate \\
\hline 3 & Marketing & 2.651 & Poor \\
\hline
\end{tabular}

Source: Processed primary data (2015)

The community perception of marketing is lower compared to two other items. This because the sub terminal of agribusiness in Selupu Rejang sub-district is not utilized well by the community. The location of agropolitan and sub terminal of agribusiness in Selupu Rejang District is far enough from the cultivation area. Moreover, the traders are not available in every so the farmers must sell agricultural products to a village or small collectors around their location at a relatively lower price.

\subsubsection{Impacts on Socio-Cultural Society}

The public perception in term of the perceived impacts on socio-cultural society development is indicated in table 4.

Table 5. Impacts on Socio-Cultural Society

\begin{tabular}{|l|l|l|l|}
\hline No & Items & Average scores & Categories \\
\hline 1 & Social & 2.490 & Moderate \\
\hline 2 & Theft & 1.921 & Poor \\
\hline 3 & Violence & 1.475 & Poor \\
\hline 4 & Political & 2.899 & Moderate \\
\hline
\end{tabular}

Source: Processed primary data (2015)

Public perceptions of the impact of agropolitan development are considered to have a positive impact on the social conditions of the community who live in agropolitan areas. There is a low level of theft and a sense of conducive is always felt by the community because of the low level of violence that occurs both in the household and between communities. This positive condition is indicated because there are a lot of jobs that can be utilized by the community. Even though they do not have agricultural land, they still can work as laborers or sellers of other services, so that the household economic turnover can be maintained.

\section{Conclusion and Recommendation \\ 4.1 Conclusion}

From the results and discussions, it can be concluded that the development of agropolitan areas when the resources are managed and utilized well by the community can suppress the growth of poverty level in the region, so that the condition of the household's economy can increase. The public perception of the direct impact of the agropolitan area development is perceived to give a positive contribution therefore the development of agropolitan areas in District Selupu, Rejang Lebong regency is worth to continue to be developed and considered.

\subsection{Recommendation}

Some suggestions that can be given based on the results of this study are as follows:

- Increasing the role of government with the improvement of infrastructure and its use in agropolitan area development, establishment of new business opportunities such as the processing industries associated with agriculture that have a competitive advantage to increase the added value of agricultural products in order to encourage more positive economic growth.

- Improving performance of working groups of agropolitan programs in accordance with the authority and focus of each work and socializing in term of the agropolitan area and enhancing promotion of the existing agropolitan area in Rejang Lebong Regency.

\section{References}

[1] Rusastra, I W., P. Simatupang dan B. Rachman. 2002. Pembangunan Ekonomi Pedesaan Berbasis Agribisnis. Analisis Kebijakan: Pembangunan Pertanian Andalan Berwawasan Agribisnis (Editor: T. Sudaryanto, et.al., 2002). Monograph Series No.23. Pusat Penelitian Sosial Ekonomi Pertanian, Bogor.

[2] Collier, W.L., K. Santoso, Soentoro, and R. Wibowo. 1993. A New Approach to Rural Development in Java: Twenty Years of Village Studies. PT. Intersys Kelola Maju. Jakarta.

[3] Sumirin Teguh 2008. Evaluasi dampak program pengembangan agropolitan terhadap kesejahteraan masyaraka, Postgraduate Bogor Agricultural University, Bogor. 